\title{
Topical Suspension Spray Dosage Form
}

National Cancer Institute

\section{Source}

National Cancer Institute. Topical Suspension Spray Dosage Form. NCI Thesaurus. Code C149420.

Liquid, usually multidose preparation consisting of a suspension in a pressurized container with a spray valve or in a container equipped with a spray pump, intended for cutaneous use. 